\title{
COMPENSATION OF MORAL DAMAGE IN RUSSIA AND THE ANGLO- SAXON LEGAL SYSTEM COUNTRIES
}

\author{
Yuliya V. Boltenkova ${ }^{1}$, Vladimir S. Sinenko ${ }^{2}$, Anastasia V. Abramova ${ }^{3}$, Ludmila N. Menyailo ${ }^{4}$, Aleksey Yu.
} Gordeev $^{5}$

${ }^{1,2,3}$ Belgorod State University, 85 Pobedy Street, Belgorod, the Belgorod region, 308015, Russia, ${ }^{4,5}$ Putilin Belgorod Law Institute of Ministry of the Interior of Russia, 71 Gorky Street, Belgorod, the Belgorod region, 308024, Russia.

Email: ${ }^{1}$ asia@prescopus.com, ${ }^{2}$ michael.1@prescopus.com, ${ }^{3}$ peter.seliverstov@prescopus.com, ${ }^{4}$ editor@prescopus.com, russia@prescopus.com

Article History: Received on $25^{\text {th }}$ July 2019, Revised on $01^{\text {st }}$ September 2019, Published on $12^{\text {th }}$ October 2019

\begin{abstract}
Purpose: The article analyzes the concepts used in the institute of compensation for moral damage in Russia and the countries of the Anglo-Saxon law system.

Methodology: Various general scientific methods and the methods of logical cognition are used in the work: analysis and synthesis, system-ic, functional and formal-logical approaches. The development of conclusions was facilitated by the application of formal-legal and comparative-legal methods.

Result: The article reveals the grounds for compensation for moral damage in Russia, England, and the USA. The author refers to the similarities and differences of the institute of compensation for moral damage in these countries. The conclusion about the need for unification of the institution in various legal systems.
\end{abstract}

Applications: This research can be used for the universities, teachers and education students.

Novelty/Originality: In this research, the model of the compensation of moral damage in Russia and the Anglo-Saxon legal system countries is presented in a comprehensive and complete manner.

Keywords: moral damage, mental suffering, compensation, physical or moral suffering, non-pecuniary damage, psychological injury.

\section{INTRODUCTION}

The world community pays significant attention to the protection of human rights and freedoms. The Universal Declaration of Human Rights, the International Covenant on Civil and Political Rights (Young, G. 2008; Bornstein, B.H., Schwartz, S.L. 2009) enshrines fundamental human rights and freedoms, paying particular attention to the natural and inalienable rights of individuals, which include the right to life, the integrity of the person, the right to honor and dignity and other rights.

Legal acts recognize certain natural human rights and establish the obligation of the state to ensure compliance with and adequate protection of human rights and freedoms. For example, the Constitution of the Russian Federation in article 2 stipulates that «A person, his rights and freedoms are the highest value. The recognition, observance, and protection of the rights and freedoms of man and citizen shall be the obligation of the State».

One type of harm that can be inflicted on a person is moral damage. The compensation of moral damage as a legal institution in Russia began to develop relatively recently.

One type of harm that can be inflicted on a person is moral damage. Non-pecuniary damage as a legal institution in Russia began to develop relatively recently. As a result, the institute is in its infancy and adaptation to the realities of the Russian legal reality. The situation is different in the countries of the Anglo-Saxon legal system. In these countries, there is a wealth of experience in the legal regulation of moral damage compensation.

A comparative legal analysis of the institute of compensation for moral damage in Russia and the countries of the AngloSaxon legal system, namely in England and the USA, will make it possible to identify and find possible solutions to problematic and debatable issues in Russian law. In particular, such problems include the lack of a unified approach to the issues of the basis for non-pecuniary damage compensation, determining the amount of compensation, correlation with other types of harm and others. Unambiguous answers to these questions in Russian law are absent.

This explains the relevance of a comparative analysis of the institution of compensation for moral damage in Russia and the countries of the Anglo-Saxon legal system.

\section{METHODS}

Various general scientific methods and the methods of logical cognition are used in the work: analysis and synthesis, systemic, functional and formal-logical approaches. The development of conclusions was facilitated by the application of formal-legal and comparative-legal methods. 


\section{DISCUSSION AND RESULTS}

In accordance with Art. 151 of the Civil Code of the Russian Federation, the Russian legislator by moral damage means physical or moral suffering caused by actions that violate the personal non-property rights of a citizen or impinge on his intangible benefits.

Non-material benefits may belong to a citizen from birth or by virtue of the law. Such non-material benefits include life, health, personal dignity, business reputation, privacy, personal and family secrets, name, authorship, freedom of movement, freedom to choose a place of residence and others.

The Russian legislator regards moral damage as: 1) moral experiences associated with the death of relatives; 2) it is impossible to continue an active social life, loss of work; 3) the disclosure of family, medical secrets; 4) the dissemination of false information, spoiling the honor, dignity or business reputation of a citizen; 5) temporary restriction or deprivation of any rights; 6) physical pain associated with injury, other damage to health or in connection with the disease.

In the countries of the Anglo-Saxon legal system (first of all, the United States and Great Britain) there is a similar legal institution. However, the term "psychological injury" is commonly used.

Psychological injury is commonly understood as «suffering, or injury caused to a person that may be a worsening of a preexisting condition and that negatively impacts functional activity...leading to claims in court for damages» (5 ). Moral damage is defined in the law of England and the United States as «psychological injury», «psychiatric injury», «nervous shock», «ordinary shock» (Kane, A. W., Dvoskin, J. A. 2011; Poser, S., Bornstein, B.H., \& McGorty, E. K. 2003; Zavos, H. 2009).

Differentiation of terminology in the law of England and the United States due to the form of guilt. The legislation of these countries establishes significantly different grounds for liability depending on whether moral damage has been caused intentionally or due to negligence.

Of particular interest is the mental damage caused by negligence. Since the qualification of the act and the determination of the grounds for compensation for non-pecuniary damage depend on the form of guilt, let us consider in more detail what the concept of "nervous shock" includes.

Under the nerve shock in the legal literature of the countries of the Anglo-Saxon law system usually, understand the psychological injury caused by negligence. Such harm can be expressed, firstly, in a mental disorder that is possible to diagnose and confirm with a medical certificate. Negative emotional shock, expressed in the form of such emotions like fear, grief, etc., cannot qualify as a nervous shock. Secondly, in the event that the claimant suffered injuries or there were reasonable grounds to assume that such injuries could have been caused; there are also grounds for bringing a claim arising from the infliction of a nervous shock. There is another reason for bringing such a claim - if the plaintiff suffered suffering, as a direct witness of harm to a person with whom the claimant is in particularly close relations.

According to the general tort law, for a long time, the plaintiffs could seek moral damage compensation for causing mental harm only if it was received as a result of physical injuries, or if psychological traumas corresponded to their physical injuries (8). However, at present, compensation may be awarded for the infliction of exclusively mental harm that is not related to physical damage.

The plaintiff must prove that the defendant's actions or omissions entailed moral damage. The victim may receive compensation for economic damage (for example, compensation for medical treatment, lost wages) or non-economic damage, which may include pain and suffering, loss of sleep and appetite. Psychological injuries mainly fall into the category of non-economic losses, since their intangible nature makes it difficult to determine the exact amount of compensation. In court, evidence of psychological injury is usually presented by the plaintiffs themselves and / or their attending physicians, who are engaged in the recovery of the plaintiffs' mental health (Smith, D. 2007; Watanabe, N. 2019; Emam, S. S., \& Shajari, H. 2013; Suleri, J., \& Cavagnaro, E. 2016; Mollaei, B., Gorji, Y., \& Rezaei, F. 2014; Manapov, K. B. 2018).

The significant differences between the institution of compensation for moral damage in the countries of the Anglo-Saxon legal system and in Russia are not only in the differentiation of the moral damage types. Such differences are also the basis of liability for causing harm (Tabunshikov, A. T., Anisimov, V. A., Levchenko, V. E., Shadzhe, M. G., \& Thabisimov, H. A. (2018).

As mentioned earlier, liability for causing moral harm in the countries of Anglo-Saxon law differs depending on the intent of the perpetrator. In Russia, as a general rule, in accordance with Article 1100 of the Civil Code of the Russian Federation, the moral damage shall be compensated regardless of the guilt of the inflictor of damage in cases where:

- Injury has been inflicted the life or health of an individual by a source of special danger;

- Damage has been done to an individual as a result of his illegal conviction, the illegal institution of proceedings against him, the illegal application of remand in custody as a measure of suppression or of a written understanding not to leave his place of residence, the illegal imposition of the administrative penalty in the form of arrest or corrective labour;

- Damage has been inflicted by the spread of information denigrating the honor, dignity and business standing; 
- In other cases provided for by the law.

In the countries of Anglo-Saxon law a person may be held liable for the careless infliction of mental damage if there are the following reasons:

- The person who caused the harm was obliged to take the necessary care with regard to the victim;

- The injurer violated this duty;

- As a result of the violation, the victim suffered mental harm, the offensive of which the perpetrator could reasonably have assumed.

It should be noted that the legislator in determining the possibility of the defendant in a lawsuit to inflict moral damage through negligence to foresee the infliction of moral damage to the claimant proceeds from the principle according to which the offender is not responsible for the harm that could not be foreseen, and he is not responsible for any harm that anyone could have foreseen. Thus, foreseeability is a necessary, but not sufficient condition for the occurrence of responsibility for causing moral damage through negligence.

An interesting point is a compensation for mental harm provided for by defamation, that is, by disseminating information that diminishes the honor and dignity of the victim.

In English law, there is a division of defamation into two types - qualified slander («libel») and simple slander («slander»). Qualified slander includes the dissemination of information discrediting the honor and dignity of a person, in written and another form, giving the dissemination of information permanent, temporary slander lies in the temporary (transitory) nature of the spread of such information.

In addition to spreading information in written form defining the honor and dignity of a person in a written form, a certain arrangement of material objects can be recognized as a qualified slander. Thus, the image of a person not found guilty of murder by a court decision, placed next to the images of persons proven guilty of murder, is an example of a qualified slander.

Qualified libel acts as an independent cause of action and may contain corpus delicti, that is, entail criminal liability. A simple libel forms an independent action if:

- It is associated with an insult to the person. In this case, the actions of the perpetrator may be regarded as a crime;

- The information disseminated contains information on the commission of a crime by the victim, for which the penalty is imprisonment;

- The disseminated information contains information about the presence of a serious or contagious disease, including venereal

- The statement includes information about the intimate aspects of a woman's life and her sexual contacts (Alekseev, S. S. (2001));

- Information detracts from the victim's business, professional or commercial reputation.

Despite the common legal systems of England and the United States, causing similarities in the legal regulation of relations arising in connection with the infliction of mental harm, the institute of compensation for moral harm in each of these countries has its own characteristics.

Due to the nature of the form of the territorial structure of the United States, each state has its own legal system, and depending on this approach to compensating for moral damage may vary significantly depending on the territorial unit of the United States.

At the same time, there are common criteria for all states to determine the basis of responsibility for causing moral damage. These include:

- The presence of intent or negligence in causing harm. Depending on the form of guilt, the nature of the legal consequences is determined;

- A causal link between the actions of the perpetrator and the mental harm caused to the victim by a reasonable and timely fear about himself or another person, injuries or physical impact, physical or mental disorder.

Moral damage compensation is appointed if mental harm is caused by negligence and is associated with personal injury. In cases where careless actions of a person have only inflicted moral damage on a victim, he is usually not compensable. American courts consider justifying the award of compensation for mental harm to a person whose emotional anxiety manifested itself through physical disorder, such as a heart attack, high blood pressure, loss of sleep, etc (Safuanov, F. S. (2016)).

There are a number of exceptions to the general rule, and recently there has been a tendency to increase the number of such exemptions from the general rule. This is due to the fact that the US courts seek to minimize the likelihood of the avoid- 
ance of liability by the offender, who acted intentionally or with gross negligence and caused serious psychological trauma to the victim (Martins, V. F., Sampaio, P. N. M., Cordeiro, A. J. A., \& Viana, B. F. 2018).

\section{CONCLUSION}

In recent years, there has been a trend towards the active development of the institute of moral damage compensation. This is due to the fact that the named institution is the most effective, and in some cases the only way to restore the violated natural personal non-property rights of a person. In Russia, the institute of compensation for moral damage appeared relatively recently and is in its infancy, while in the countries of the Anglo-Saxon system of law compensation for mental harm has been regulated in some detail and has been successfully used for a long time (Romanchuk, S. V., \& Racheva, S. S. $\underline{(2017))}$.

Compensation of moral damage in the Anglo-Saxon legal system, considered on the example of England and the United States, is distinguished by a wide separation of types of moral damage, differentiation of the grounds for responsibility for causing moral damage, depending on the form of guilt, as well as attribution of the act that caused mental harm to a person to categories of offenses or crimes.

In Russia at present, the institute of compensation for moral damage is in its formative stage. Nevertheless, some tendencies of the development of this institute are already outlined. The tendencies include the development of a terminological base, the addition, and expansion of the content of moral damage. Comparing the responsibility for causing moral damage in Russia and the countries of the Anglo-Saxon legal system, we can conclude that the Russian legislator pays more attention to the protection and restoration of the individual's right to honor, dignity and business reputation than in England and the USA. Most of the acts regarded in the countries of the Anglo-Saxon system of law as simple slander and attributable to the category of offenses in Russia qualify as a crime and incur more severe punishment (Volkova, V. V., Sapfirova, A. A., \& Petrushkina, A. V. (2016)).

The study of the positive experience gained by the countries of the Anglo-Saxon legal system over several centuries, its analysis and adaptation to the conditions of Russian legal realities will allow us to set the vector for the development of moral damage compensation in Russia, to improve this legal institution. That is why the conduct of comparative studies in this area is of particular interest and relevance.

\section{CONFLICT OF INTEREST}

The authors confirm that the information provided in the article does not contain a conflict of interest.

\section{REFERENCES}

1. Young, G. (2008). Psychological injury and law: Defining a field. Psychological Injury and Law, 1.78-93. https://doi.org/10.1007/s12207-008-9008-1

2. Bornstein, B.H., Schwartz, S.L. (2009). Injured body, injured mind: Dealing with damages for psychological harm. The Jury Expert, March 2009.

3. Kane, A. W., Dvoskin, J. A. (2011). Evaluation for personal injury claims. New York: Oxford University Press. https://doi.org/10.1093/med:psych/9780195326079.001.0001

4. Poser, S., Bornstein, B.H., \& McGorty, E. K. (2003). Measuring damages for life from the bench and the jury box. Law and Human Behavior, p.53-68. https://doi.org/10.1023/A:1021626928063

5. Zavos, H. (2009). The monetary damages for the economy are: Loyola of Los Angeles Law Review, 43, $193-272$. Psychol. Inj. and Law.

6. Smith, D. (2007). The disordered and discredited plaintiff: Psychiatric evidence in civil litigation. Cardozo Law Review, 31, 750-822.

7. Watanabe, N. (2019). Effective Simple Mathematics Play at Home in Early Childhood: Promoting both Noncognitive and Cognitive Skills in Early Childhood. International Electronic Journal of Mathematics Education, 14(2), 401-417. https://doi.org/10.29333/iejme/5739

8. Emam, S. S., \& Shajari, H. (2013). RECOGNITION AND ANALYSIS OF EFFECTIVE FACTORS ON INVESTORS'DECISION MAKING IN STOCK EXCHANGE OF TEHRAN, UCT Journal of Management and Accounting Studies, 1(1): 14-21.

9. Suleri, J., \& Cavagnaro, E. (2016). Promoting Pro-environmental Printing Behavior: The Role of ICT Barriers and Sustainable Values. Dutch Journal of Finance and Management, 1(1), 38. https://doi.org/10.20897/lectito.201638

10. Mollaei, B., Gorji, Y., \& Rezaei, F. (2014). Comparison of Anxiety, Children, and Single with Two Children in Secondary Schools during the First and Second Year in the Academic Year 2013-2014 of Bandar Abbas, UCT Journal of Social Sciences and Humanities Research, 2(2): 127-130.

11. Manapov, K. B. (2018). Some peculiarities of implementation of departmental control over the intelligence activities. Opción, 34, 191-205.

12. Martins, V. F., Sampaio, P. N. M., Cordeiro, A. J. A., \& Viana, B. F. (2018). Implementing a Data Network Infrastructure Course using a Problem-based Learning Methodology. Journal of Information Systems Engineering \& Management, 3(2), 10. https://doi.org/10.20897/jisem.201810 
13. Tabunshikov, A. T., Anisimov, V. A., Levchenko, V. E., Shadzhe, M. G., \& Thabisimov, H. A. (2018). Institution of compensation for moral harm in civil law of the countries of the Commonwealth of Independent States.

14. Safuanov, F. S. (2016). Forensic psychological expertise in cases of compensation of moral harm in the Russian Federation. Psychology and Law, 6(2), 26-40. https://doi.org/10.17759/psylaw.2016060203

15. Romanchuk, S. V., \& Racheva, S. S. (2017). Strengthening the Compensatory Basics for Violated Subjective Civil Rights Protection in the European Union Member States and the Russian Federation. InterEU law east: journal for the international and european law, economics and market integrations, 4(1), 1-18. https://doi.org/10.22598/iele.2017.4.1.1

16. Volkova, V. V., Sapfirova, A. A., \& Petrushkina, A. V. (2016). Justice in judicial and non-judicial practice in the administration of the Russian labor law: problems and prospects. Journal of Advanced Research in Law and Economics, 7(7 (21)), 1891-1898.

17. Alekseev, S. S. (2001). On some tendencies in world legal development and the Russian legal system. Rev. Cent. \& E. Eur. L., 27, 567. https://doi.org/10.1163/157303501124667630

18. Bitāns, A. Legal Liability for Non-pecuniary Loss in Civil Laws of Different Countries1 Juridiskā atbildība par nemantisku kaitējumu dažādu valstu civiltiesībās. Juridiskā zinātne, 112.

19. Sorokin, P. (2017). Russia and the United States. Routledge. https://doi.org/10.4324/9781315128863

20. Lazareva, O., Rachinsky, A., \& Stepanov, S. (2008). A survey of corporate governance in Russia. In Corporate governance in transition economies (pp. 315-349). Springer, Boston, MA. https://doi.org/10.1007/978-0-387$\underline{84831-0 \_32}$ 